\title{
USULAN SISTEM PENGOLAHAN DATA SISWA DI SMP HARAPAN ANANDA KUBU RAYA
}

\author{
Muhamad Arpan', Ridho Dedy Arief Budiman², Nizwardi Jalinus ${ }^{3}$ \\ ${ }^{1,2}$ Program Studi Pendidikan Teknologi Informasi dan Komputer \\ Fakultas Pendidikan MIPA dan Teknologi IKIP PGRI Pontianak, Jalan Ampera No.88 Pontianak \\ ${ }^{3}$ Fakultas Teknik Universitas Negeri Padang \\ Jalan Prof. Dr. Hamka, Air Tawar Barat, Padang Utara, Padang, Sumatera Barat \\ ${ }^{1}$ e-mail: arpanmuhamad@gmail.com
}

\begin{abstract}
Abstrak
Tujuan penelitian adalah menganalisis kebutuhan sistem pengolahan data siswa di SMP Harapan Ananda Kubu Raya. Metode penelitian adalah deskriptif. Subjek penelitian adalah siswa dan guru SMP Harapan Ananda Kubu Raya. Alat pengumpulan data menggunakan wawancara dengan teknik pengumpul data menggunakan panduan wawancara. Teknik analisis data menggunakan analisis deskriptif. Analisis sistem pengolahan data siswa SMP Harapan Ananda Kubu Raya yang dilakukan meliputi nilai, daftar hadir, dan aktivitas non-akademis yang melibatkan siswa. Hasil penelitian berbentuk alur program yang digunakan untuk melakukan pengolahan data yang menghasilkan output berupa data siswa. Semua data siswa disimpan dalam database dengan bahasa pemrograman PHP dan MySQL sehingga dapat dengan mudah diakses saat diperlukan.
\end{abstract}

Kata Kunci: analisis, database, PHP, MySQL.

\begin{abstract}
The purpose of the study was to analyze the need for data processing systems for students at SMP Harapan Ananda Kubu Raya. The research method was descriptive. The research subjects were students and teachers of SMP Harapan Ananda Kubu Raya. The data collection tool used interviews with data collection techniques using interview guides. The data analysis technique used descriptive analysis. The analysis of the data processing system of students of SMP Harapan Ananda Kubu Raya included students' grades, attendance lists, and non-academic activities. The results of the study were the form of program flow that is used to process the data. The process produces the output in the form of students' data. Data of all student stored in a database with the PHP and MYSQL programming languages so that it can be easily accessed when needed.
\end{abstract}

Keywords: analysis, database, $P H P, M y S Q L$.

\section{PENDAHULUAN}

Perkembangan sistem informasi baik perangkat keras maupun lunak pada hakekatnya adalah diarahkan untuk mencapai kemajuan, seperti menyelesaikan berbagai bidang pekerjaan, khususnya bagi dunia pendidikan. Komputer dapat melaksanakan berbagai jenis pengolahan data yang dapat dilaksanakan oleh manusia dengan lebih cepat dan dengan tingkat kesalahan yang lebih sedikit. Dengan pengolahan data yang lebih baik, maka informasi yang dihasilkan dapat lebih berkualitas sehingga dapat membantu pihak pemakai untuk menghasilkan suatu solusi yang lebih baik dalam memecahkan permasalahan yang terjadi. 
Dengan demikian, komputer mempunyai peranan yang signifikan dalam membantu menghasilkan keputusan yang lebih baik.

Setiap sekolah melakukan pengolahan data siswa. Sistem pengolahan data yang baik dapat digunakan tidak hanya untuk penyimpanan data secara elektronik saja tetapi harus mampu mendukung proses analisis yang diperlukan oleh pihak sekolah. Setiap sekolah melakukan pengolahan data yang pada akhirnya akan memperlihatkan hasil belajar dan perkembangan siswa dalam satu semester pelajaran. Berdasarkan hasil pengolahan data tersebut, orang tua siswa, wali kelas, guru, siswa dan kepala sekolah melakukan perencanaan belajar untuk semester berikutnya.

Berbagai proses yang berkaitan dengan pengolahan data nilai siswa dikerjakan secara manual sebagaimana proses pencatatan administrasi sekolah lainnya, data nilai siswa dikumpulkan dari guru mata pelajaran dan wali kelas dalam bentuk lembaran arsip nilai, kemudian dilakukan perhitungan nilai yang dikerjakan secara manual, data nilai hasil olahan tersebut direkapitulasi dalam bentuk raport yang juga ditulis dengan tangan dalam buku raport yang sudah disediakan. Semua arsip yang dihasilkan tersebut disimpan dalam lemari penyimpanan data. Salah satu sekolah yang masih menggunakan mekanisme tersebut adalah SMP Harapan Ananda Kubu Raya. Oleh karenanya, dengan ditunjang dengan fasilitas yang tersedia, SMP Harapan Ananda Kubu Raya sebagai salah satu lembaga pendidikan formal swasta akan memanfaatkan komputer sebagai sarana pengolahan data agar lebih efektif dan efisien (Lubis dan Ginting, 2016: 110; Tarigan, dkk., 2016: 4; Matondang, dkk., 2016: 16; Aniskurlillah dan Sembiring, 2016: 28; Wahyudi, dkk., 2015: 73; Wahyuni dan Hapsara, 2015: C-11).

SMP Harapan Ananda Kubu Raya dalam pengolahan data dan administrasinya menggunakan aplikasi Microsoft Office, namun masih sering menimbulkan masalah karena data yang diolah tidak dapat diakses secara bersamaan dan hanya berpusat pada satu komputer. Dampak yang ditimbulkan adalah lambatnya proses pengolahan data sehingga mengakibatkan lambatnya penyajian informasi yang diperlukan oleh orang tua siswa. Ketika ingin 
melakukan pencarian data, pengguna harus mencari dan membuka file yang ada satu per satu secara manual di komputer. Aplikasi yang digunakan tidak memfasilitasi pencarian secara terkomputerisasi. Akibatnya sulit menyajikan informasi yang berkualitas dan tepat waktu. Dengan menggunakan sistem terkomputerisasi, maka informasi yang disajikan akan lebih akurat dan mempersingkat waktu pencarian (Tinambunan, dkk., 2018: 295; Halawa, 2016: 66; Bakti, dkk., 2016: 32; Syapnika dan Siagian, 2015: 32; Zukhri dan Winarko, 2014: B-50).

Adanya perbedaan antara harapan dan kenyataan membuat peneliti tertarik untuk mengangkatnya dalam sebuah penelitian. Hal tersebut yang mendasari peneliti untuk melakukan penelitian di SMP Harapan Ananda Kubu Raya. Peneliti membahas mengenai Pengolahan Data Siswa SMP Harapan Ananda Kubu Raya yang meliputi nilai, daftar hadir, dan aktivitas non-akademis yang melibatkan siswa. Sistem yang akan dihasilkan berbentuk sebuah program yang digunakan untuk melakukan pengolahan data untuk menghasilkan output berupa data siswa. Semua data siswa disimpan dalam database dengan bahasa pemrograman PHP dan MySQL sehingga dapat dengan mudah diakses saat diperlukan.

\section{METODE}

Penelitian menggunakan metode deskriptif. Subjek penelitian adalah siswa dan guru SMP Harapan Ananda Kubu Raya. Alat pengumpulan data menggunakan wawancara dengan teknik pengumpul data menggunakan panduan wawancara. Teknik analisis data menggunakan analisis deskriptif. Penelitian membahas tentang permasalahan dalam penerapan Sistem Pengolahan Data Siswa di SMP Harapan Ananda Kubu Raya yang meliputi nilai, daftar hadir, dan aktivitas non-akademis yang melibatkan siswa.

\section{HASIL DAN PEMBAHASAN}

Analisis sistem dilakukan dengan tujuan untuk mengidentifikasi masalahmasalah yang sedang terjadi pada sistem berjalan sehingga dapat dilakukan perbaikan-perbaikan terhadap kelemahan sistem tersebut. Analisis sistem berjalan 
dilakukan dalam tiga tahap, yaitu identifikasi masalah, identifikasi penyebab masalah, dan hasil analisis.

\section{Identifikasi Masalah}

Permasalahan yang ditemukan dari hasil mengidentifikasi masalah pada sistem pengolahan data nilai siswa pada SMP Harapan Ananda adalah: (1) Penggunaan aplikasi tatap muka yang bersifat umum (general), yaitu aplikasi Microsoft Office. Banyaknya menu yang tidak berhubungan dengan pengolahan data mengakibatkan munculnya kesulitan dan kebingungan bagi pengguna; (2) Belum menggunakan database yang terintegrasi. Semua arsip data disimpan sebagai tumpukkan file komputer yang terus bertambah serta mengalami redundansi dalam penyimpanannya. Untuk mengakses arsip data dalam pencarian informasi, harus dilakukan dengan membuka aplikasi satu demi satu; (3) Setiap awal tahun ajaran, format pengisian nilai harus dibuat ulang untuk menyesuaikan nama dan kelas siswa sesuai data tahun ajaran baru. Format pengisian nilai tahun ajaran sebelumnya tidak dapat dipergunakan lagi dan hanya akan disimpan sebagai arsip. Perubahan tersebut dilakukan secara manual per kelas dan per mata pelajaran. Hal tersebut tentu saja menghabiskan waktu dan tenaga; (4) Jika terjadi perubahan data siswa akibat adanya siswa yang pindah sekolah, akan menyebabkan perubahan daftar nama pada format pengisian nilai. Adapun perubahan harus dilakukan secara manual untuk setiap worksheet yang jumlahnya cukup banyak; dan (5) Sering terjadi kesalahan input data nilai yang menyebabkan raport yang telah dicetak harus diperbaiki sehingga terjadi pemborosan sumber daya bahkan dapat mengalami keterlambatan pembagian raport. Hal tersebut disebabkan aplikasi belum memiliki validasi data yang dapat memberi peringatan akan kesalahan proses input. Rumus yang disediakan dalam berbagai perhitungan maupun proteksi dapat terhapus secara tidak sengaja sehingga keandalan program menjadi terganggu.

\section{Identifikasi Penyebab Masalah}

Analisis sistem dilakukan untuk mengetahui kelemahan-kelemahan yang terjadi pada sistem berjalan pada Sistem Pengolahan Data Siswa SMP Harapan Ananda. Dari hasil analisis terhadap tata laksana sistem yang sedang berjalan 
dapat disimpulkan bahwa penyebab masalah pada sistem berjalan yaitu belum adanya aplikasi yang dirancang khusus untuk melakukan pengolahan data nilai siswa yang mendukung: (1) Kemudahan penggunaan (user friendly) karena layar kerja yang dirancang khusus untuk melakukan pengolahan data nilai; (2) Database terintegrasi sehingga terhindar dari redundansi data sekaligus memudahkan pencarian data; (3) Fleksibel terhadap perubahan data maupun format; dan (4) Kemampuan validasi kesalahan dalam proses input data. Hal tersebut sesuai dengan penelitian Ulfa dan Syahrizal (2016: 64) yang menyatakan bahwa dengan menerapkan sistem komputerisasi, maka proses pengolahan data akan semakin tepat dan mengurangi kesalahan dalam memprediksi.

\section{Hasil Analisis}

Berdasarkan pada identifikasi masalah dan penyebab masalah yang telah diuraikan, maka peneliti mengambil kesimpulan bahwa masalah-masalah utama yang dihadapi pada sistem pengolahan data siswa pada SMP Harapan Ananda dapat diatasi dengan merancang aplikasi baru yang khusus untuk melakukan pengolahan data nilai siswa. Aplikasi tersebut mempunyai nilai lebih dibanding aplikasi yang sudah ada karena penggunaannya bersifat berkesinambungan dan mudah menyesuaikan dengan perubahan format dan data, tampilan yang mudah dipahami penggunaannya serta validasi data masukan. Dengan penggunaan aplikasi baru, terdapat penyederhanaan proses sehingga sistem lebih ringkas dan terotomatisasi serta memudahkan pengguna dalam memproses data yang diperlukan. Hal tersebut sesuai dengan penelitian Berutu (2016: 96) yang menyatakan bahwa dengan penerapan aplikasi komputerisasi, maka akan diberikan kemudahan dan kenyamanan dalam penggunaannya.

Berdasarkan hasil analisis yang dilakukan, maka peneliti mengusulkan rancangan sistem usulan berupa sistem pengolahan data nilai siswa yang mampu mengatasi permasalahan yang dihadapi sistem berjalan. Adapun perbaikan yang terjadi pada sistem usulan berupa penyederhanaan proses yang ada pada sistem berjalan (simplifying). Penyederhanaan yang dilakukan menyebabkan tidak perlunya pemindahan simpanan data nilai siswa kedalam daftar nilai gabungan ataupun daftar registrasi raport. Hal tersebut dikarenakan basis data yang 
digunakan telah terintegrasi dan dapat digunakan untuk semua keperluan penyiapan laporan.

Sistem usulan dikembangkan dengan pendekatan terstruktur dan teknik permodelan perancangan sistem yang berorientasi pada metodologi proses. Penggambaran sistem disajikan dalam bentuk logis berupa diagram arus data yang dilengkapi dengan kamus data. Diagram arus data menjelaskan secara detail setiap proses yang terjadi dalam sistem usulan. Tiap kamus data menerangkan secara rinci mengenai data yang mengalir dalam diagram arus data sistem usulan.

Penggambaran sistem secara logis tidak tergantung pada perangkat keras, perangkat lunak, struktur data, maupun organisasi berkas dari sistem usulan, melainkan dengan bagaimana prosedur pengolahan, penyimpanan, dan pengambilan kembali data. Permodelan logis membantu dan mempermudah pemakai untuk mengerti dan memahami apa yang dikerjakan sistem tersebut.

Analisis data dilakukan terhadap data yang telah dikumpulkan, data yang telah dikumpulkan tersebut dirancang dengan menggunakan diagram konteks dan diagram rinci.

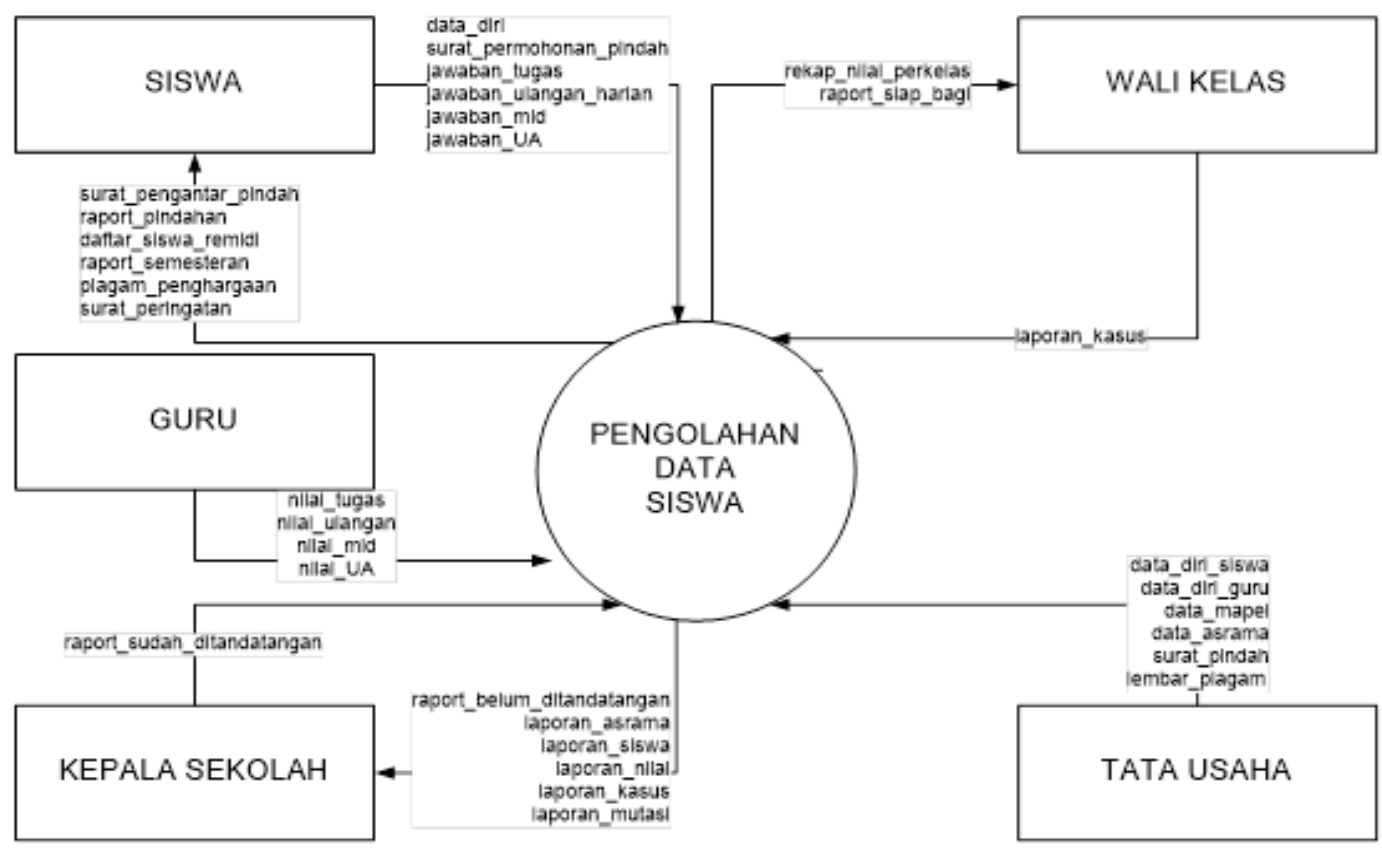
Gambar 1 Diagram Konteks Sistem Pengolahan Data Siswa Usulan di SMP
Harapan Ananda 
Gambaran sistem yang diusulkan secara umum diperlihatkan pada diagram konteks sistem pengolahan data nilai siswa yang diusulkan terlihat pada Gambar 1. Dari gambar tersebut dapat dilihat bahwa kesatuan luar yang berhubungan dengan sistem adalah Tata Usaha, Guru, Kepala Sekolah, Wali Kelas, dan Siswa. Dalam diagram konteks terlihat adanya arus data yang masuk ke dalam sistem dan arus data yang keluar dari sistem.

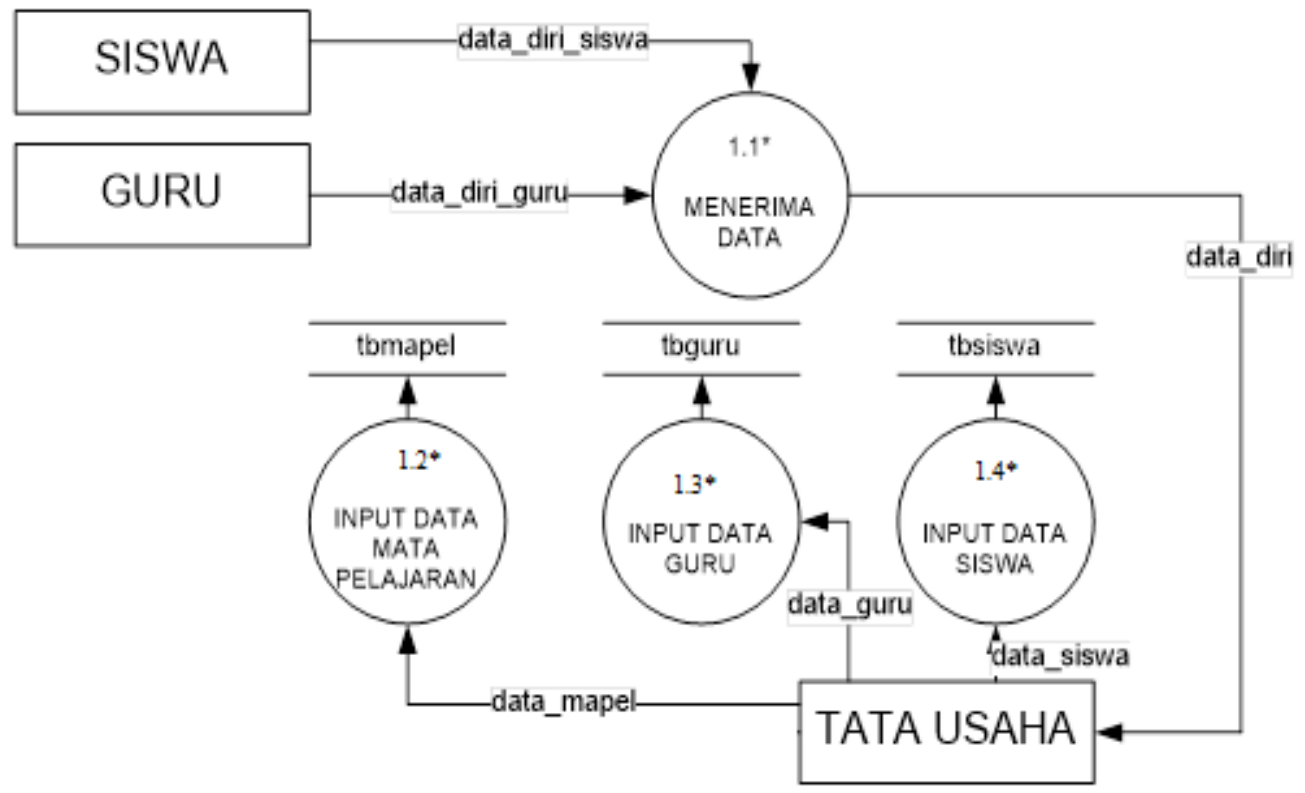

Gambar 2 Diagram Rinci 1.0 - Uraian Proses Pengisian Data
Sistem Pengolahan Data Siswa Usulan di SMP Harapan Ananda

Proses rinci 1.0 ditunjukkan pada Gambar 2 dengan detail sebagai berikut:

\section{Proses 1.1* - Menerima Data}

Tata Usaha menerima data siswa dan guru untuk direkap.

\section{Proses 1.2* - Input Data Mata Pelajaran}

Data yang telah diklasifikasikan oleh Tata Usaha akan dimasukkan dalam database mata pelajaran.

\section{Proses 1.3*- Input Data Guru}

Data yang telah diklasifikasikan oleh Tata Usaha akan dimasukkan dalam database guru.

\section{Proses 1.4* - Input Data Siswa}

Data yang telah diklasifikasikan oleh Tata Usaha akan dimasukkan dalam database siswa. 


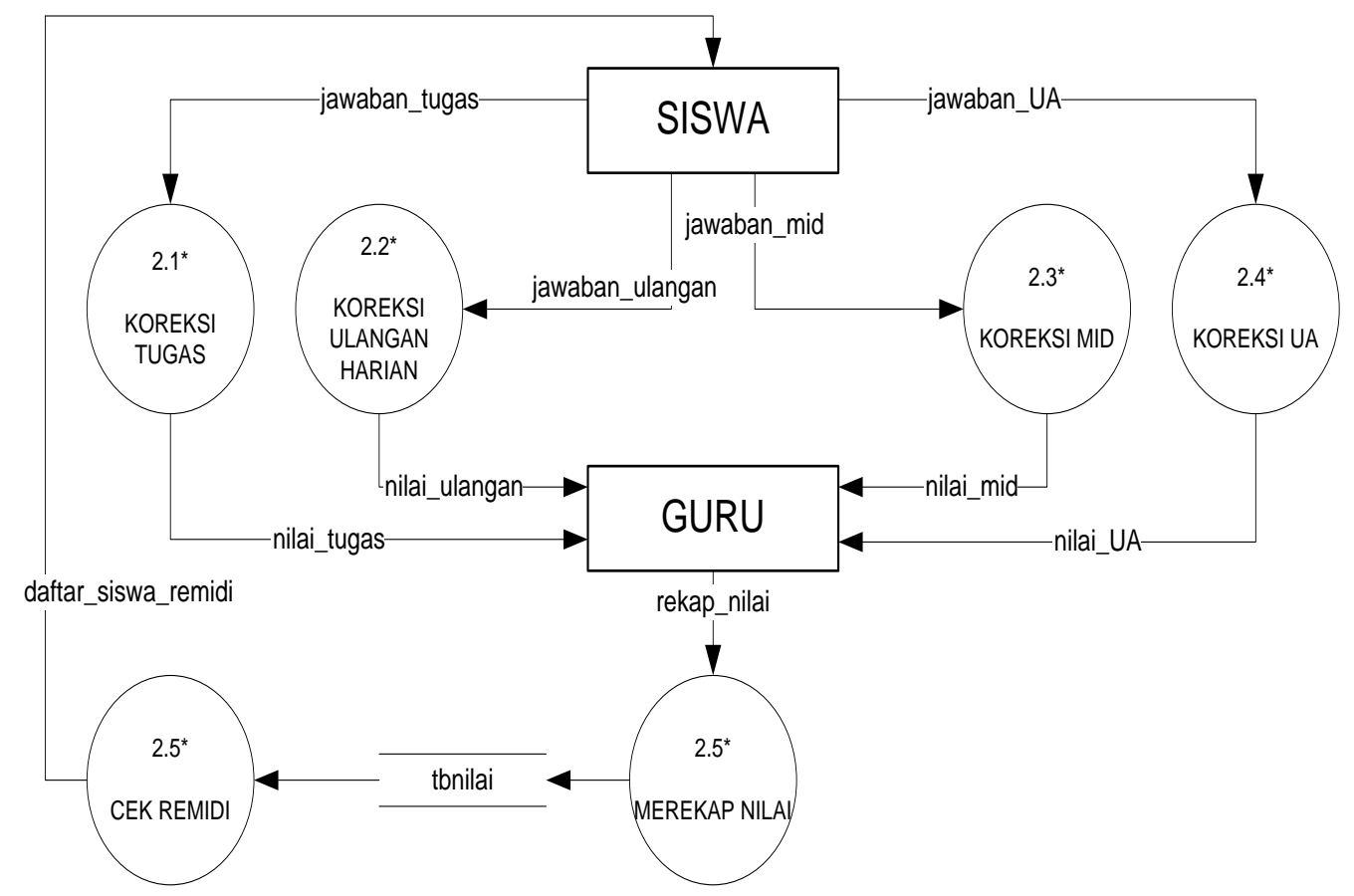

Gambar 3 Diagram Rinci 2.0 - Uraian Proses Pengolahan Nilai Sistem Pengolahan Data Siswa Usulan di SMP Harapan Ananda

Proses rinci 2.0 ditunjukkan pada Gambar 3 dengan detail sebagai berikut:

\section{Proses 2.1* - Koreksi Tugas}

Guru memeriksa jawaban tugas yang dikerjakan oleh siswa. Kemudian menghasilkan nilai tugas yang akan direkap oleh guru.

\section{Proses 2.2* - Koreksi Ulangan Harian}

Guru memeriksa jawaban ulangan harian yang dikerjakan siswa. Kemudian menghasilkan nilai ulangan harian yang akan direkap oleh guru.

\section{Proses 2.1* - Koreksi Mid}

Guru memeriksa jawaban mid yang dikerjakan siswa. Kemudian menghasilkan nilai mid yang akan direkap oleh guru.

\section{Proses 2.1* - Koreksi UA}

Guru memeriksa jawaban UA yang dikerjakan siswa. Kemudian menghasilkan nilai UA yang akan direkap oleh guru.

\section{Proses 2.5* - Merekap Nilai}

Semua nilai akan direkap oleh guru menjadi satu dan disimpan dalam database nilai. 


\section{Proses 2.6* - Cek Remidi}

Guru memeriksa standar kelulusan tiap mata pelajaran dan akan menghasilkan daftar siswa yang harus mengikuti remidi.

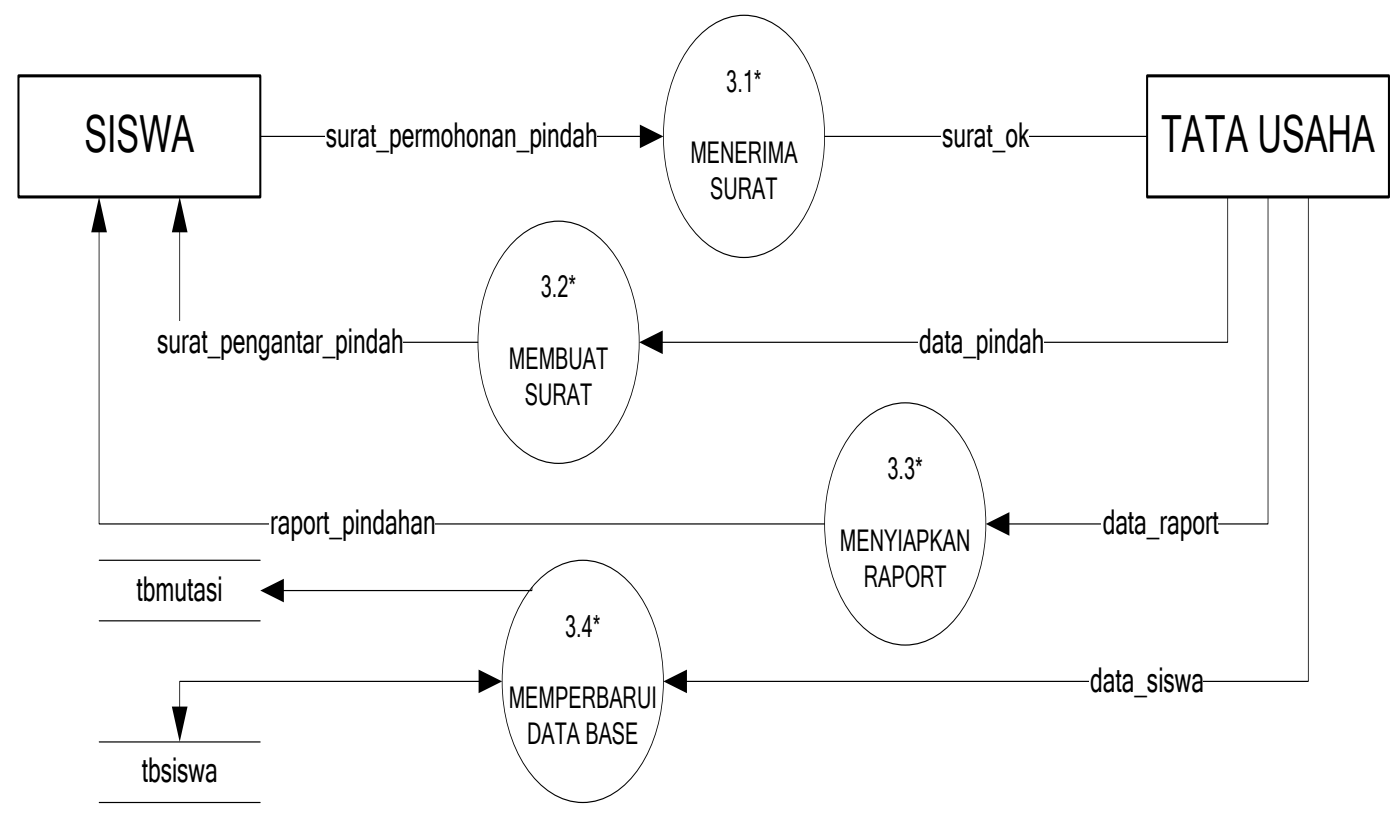

Gambar 4 Diagram Rinci 3.0 - Uraian Proses Pengolahan Mutasi Sistem Pengolahan Data Siswa Usulan di SMP Harapan Ananda

Proses rinci 3.0 ditunjukkan pada Gambar 4 dengan detail sebagai berikut:

\section{Proses 3.1* - Menerima Surat}

Tata Usaha menerima surat permohonan pindah yang diajukan oleh siswa, kemudian mengecek kelengkapan permohonan pindah tersebut.

\section{Proses 3.2* - Membuat Surat}

Tata Usaha membuat surat pengantar pindah yang ditujukan ke sekolah tujuan dan akan diserahkan ke siswa.

\section{Proses 3.3* - Menyiapkan Raport}

Tata Usaha menulis alasan pindah dan nama sekolah tujuan pada raport.

\section{Proses 3.4* - Memperbarui Database}

Tata Usaha memperbarui database siswa dan mengisi database mutasi. 


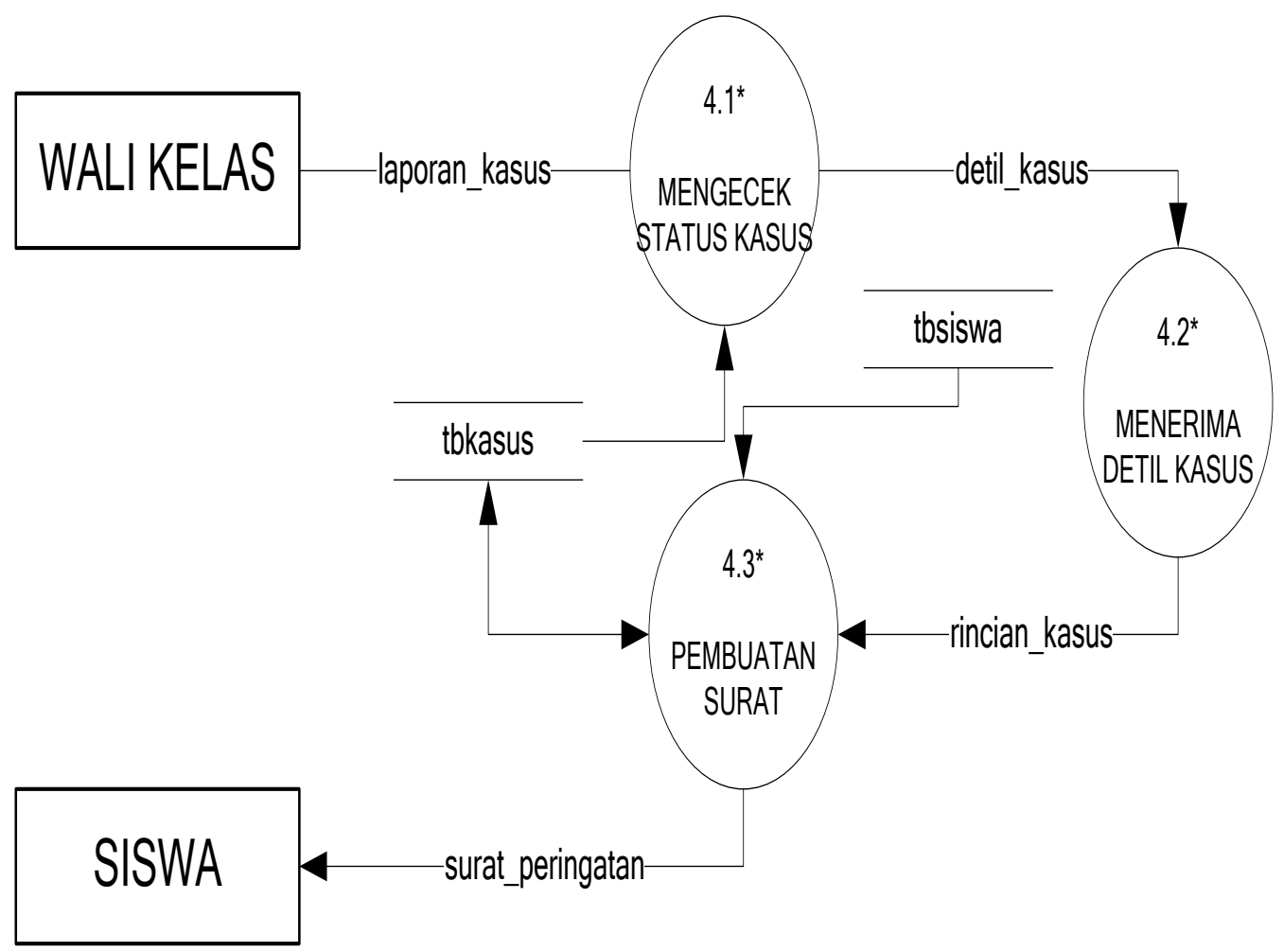

Gambar 5 Diagram Rinci 4.0 - Uraian Proses Pengolahan Kasus Sistem Pengolahan Data Siswa Usulan di SMP Harapan Ananda

Proses rinci 4.0 ditunjukkan pada Gambar 5 dengan detail sebagai berikut:

\section{Proses 4.1* - Mengecek Status Kasus}

Wali Kelas menerima laporan kasus dan mengecek status pelanggaran.

\section{Proses 4.2* - Menerima Detail Kasus}

Wali Kelas menerima detail (rincian) kasus.

\section{Proses 4.3* - Pembuatan Surat}

Wali Kelas membuat surat peringatan yang akan diberikan ke siswa dan memperbarui database kasus. 


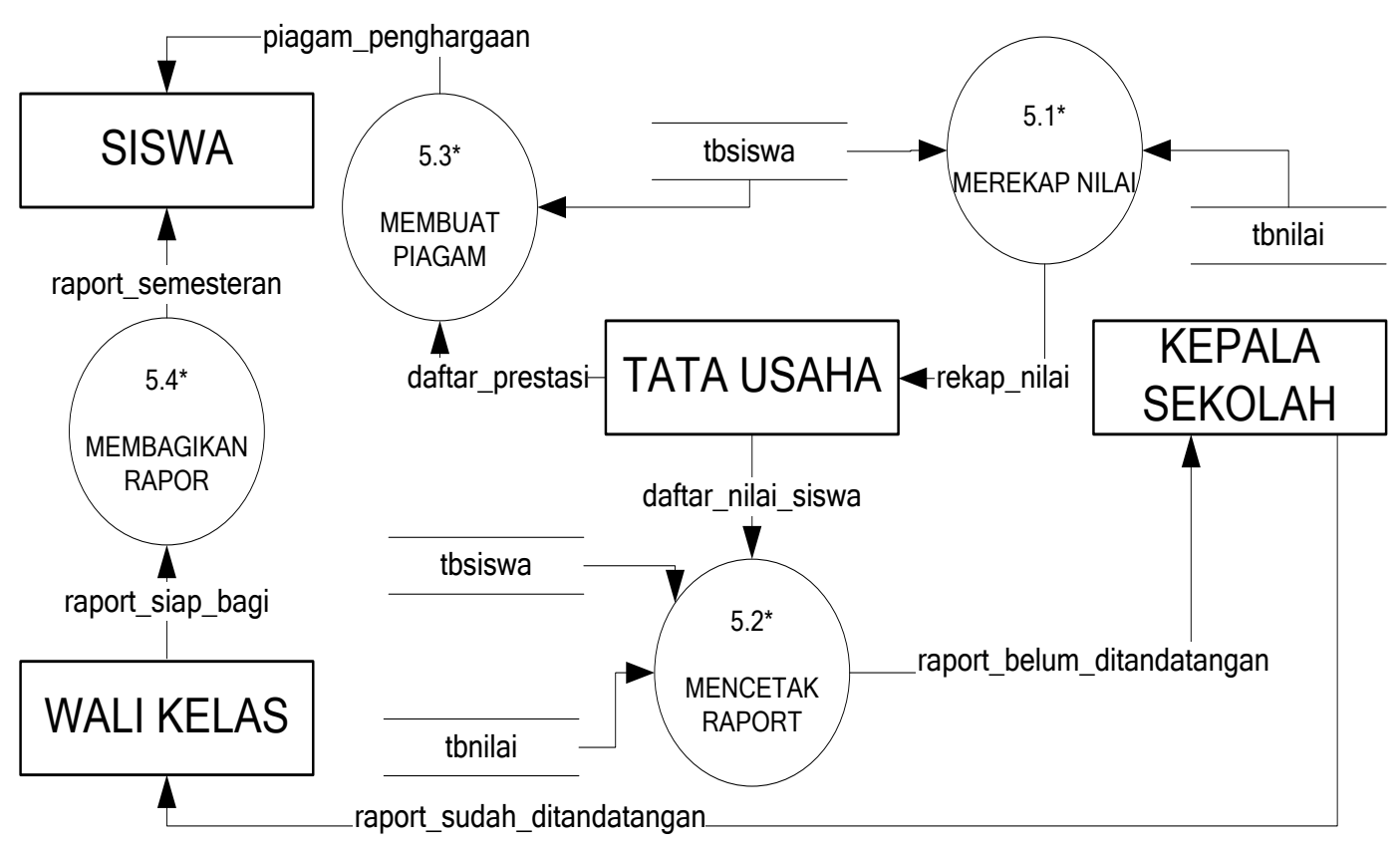

Gambar 6 Diagram Rinci 5.0 - Uraian Proses Pengolahan Raport Sistem Pengolahan Data Siswa Usulan di SMP Harapan Ananda

Proses rinci 5.0 ditunjukkan pada Gambar 6 dengan detail sebagai berikut:

\section{Proses 5.1* - Merekap Nilai}

Tata Usaha mengambil data dari database nilai untuk menghasilkan rekap nilai.

\section{Proses 5.2* - Mencetak Raport}

Tata Usaha akan mencetak raport dan memberikan raport ke Kepala Sekolah untuk ditandatangani.

\section{Proses 5.3* - Mencetak Piagam}

Tata Usaha akan mencetak piagam yang akan diberikan ke siswa pada saat pembagian raport.

\section{Proses 5.4* - Membagikan Raport}

Raport yang telah ditandatangani oleh Kepala Sekolah akan dibagikan ke siswa. 


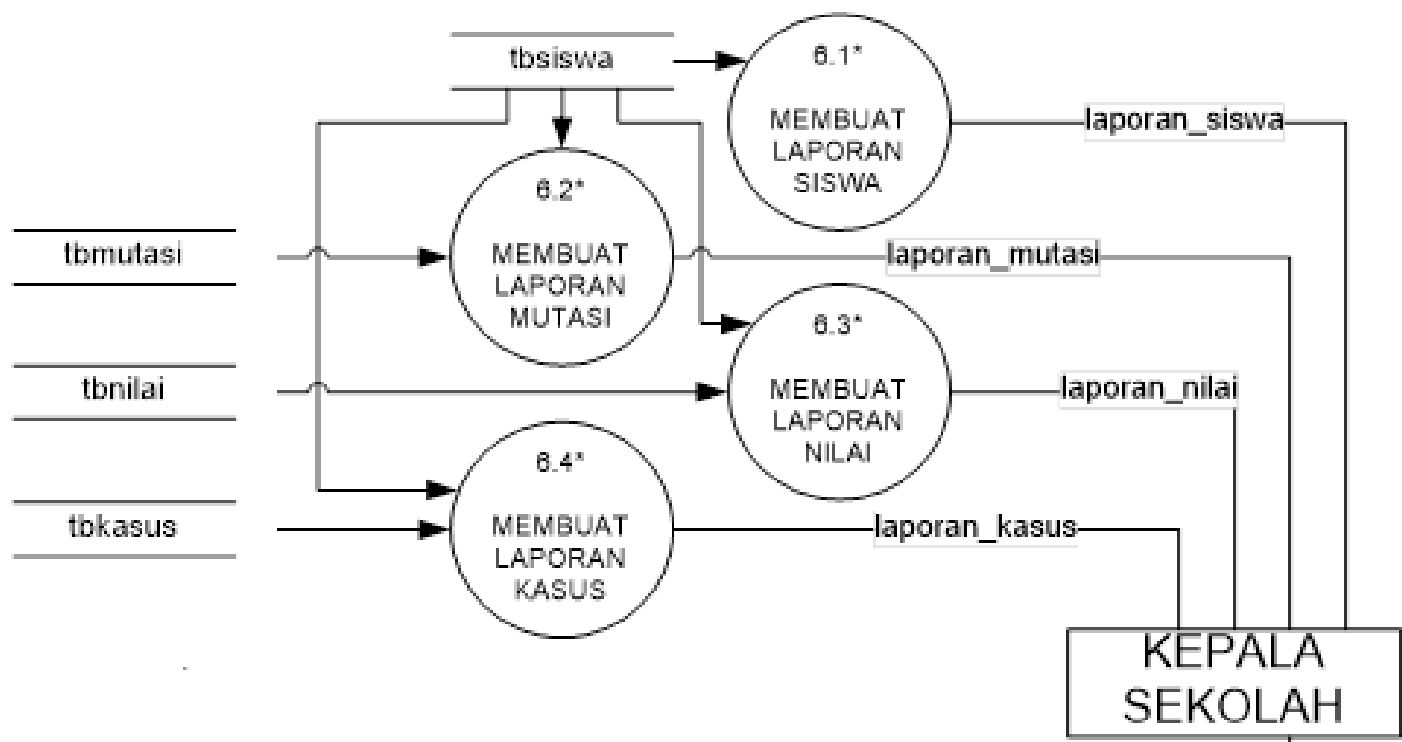

\section{Gambar 7 Diagram Rinci 6.0 - Uraian Proses Pengolahan Laporan Sistem Pengolahan Data Siswa Usulan di SMP Harapan Ananda}

Proses rinci 6.0 ditunjukkan pada Gambar 7 dengan detail sebagai berikut:

\section{Proses 6.1* - Membuat Laporan Siswa}

Pengguna mengambil data dari database siswa untuk menghasilkan laporan siswa yang akan diserahkan ke Kepala Sekolah.

\section{Proses 6.2* - Membuat Laporan Mutasi}

Pengguna mengambil data dari database mutasi untuk menghasilkan laporan mutasi yang akan diserahkan ke Kepala Sekolah.

\section{Proses 6.3* - Membuat Laporan Nilai}

Pengguna mengambil data dari database nilai untuk menghasilkan laporan nilai yang akan diserahkan ke Kepala Sekolah.

\section{Proses 6.4* - Membuat Laporan Kasus}

Pengguna mengambil data dari database kasus untuk menghasilkan laporan kasus yang akan diserahkan ke Kepala Sekolah.

\section{SIMPULAN}

Berdasarkan dari hasil analisis sistem berjalan dan desain sistem yang diusulkan, maka disimpulkan: (1) Sistem pengolahan data siswa yang diusulkan dapat membantu sekolah untuk menghasilkan output berupa daftar nilai siswa 
berdasarkan mata pelajaran, daftar mutasi siswa, daftar kasus siswa, daftar guru, dan daftar siswa berdasarkan kelas; dan (2) Sistem usulan mendukung kinerja multi-user untuk meningkatkan kinerja sekolah. Penggunaan muti-user dimaksudkan karena pada implementasi, database aplikasi akan ditempatkan di komputer pusat, kemudian aplikasi yang dijalankan di komputer pengguna akan mengakses database tersebut.

\section{UCAPAN TERIMA KASIH}

Terima kasih penulis ucapkan kepada IKIP PGRI Pontianak yang telah memberikan bantuan dana penelitian melalui LPPM IKIP PGRI Pontianak. Terima kasih juga penulis ucapkan kepada SMP Harapan Ananda Kubu Raya yang telah bersedia menjadi subjek penelitian, serta semua pihak yang telah membantu terlaksananya penelitian.

\section{DAFTAR PUSTAKA}

Aniskurlillah \& Sembiring, A. S. 2016. Perancangan Aplikasi Pembelajaran Elektronik Data Processing dengan Menggunakan Metode Computer Based Learning. Jurnal Riset Komputer (JURIKOM), 3(4): 28-31.

Bakti, S., Hasibuan, N. A., Sianturi, L. T., \& Sianturi, R. D. 2016. Perancangan Aplikasi Pembelajaran CorelDraw X3 Menggunakan Metode Web Based Learning (WBL). Jurnal Riset Komputer (JURIKOM), 3(4): 32-35.

Berutu, W. 2016. Perancangan Aplikais Palang Pintu Otomatis Menggunakan Motion Sensor Berbasis Mikrokontroler AT89S51. Jurnal Riset Komputer (JURIKOM), 3(1): 96-101.

Halawa, S. 2016. Perancangan Aplikasi Pembelajaran Topologi Jaringan Komputer untuk Sekolah Menengah Kejuruan (SMK) Teknik Komputer dan Jaringan (TKJ) dengan Metode Computer Based Instruction. Jurnal Riset Komputer (JURIKOM), 3(1): 66-71.

Lubis, N. \& Ginting, G. 2016. Perancangan Aplikasi Penjadwalan Kereta Api dengan Menggunakan Algoritma Genetika. Jurnal Riset Komputer (JURIKOM), 3(6): 110-114.

Matondang, F., Hasibuan, N. A., Saputra, I., \& Suginam. 2016. Perancangan Aplikasi Text Editor dengan Menerapkan Algoritma Knuth-Morris-Pratt. Jurnal Riset Komputer (JURIKOM), 3(4): 16-21. 
Syapnika, D. \& Siagian, E. R. 2015. Penerapan Algoritma Minimax pada Permainan Checkers. Jurnal Riset Komputer (JURIKOM), 2(6): 28-32.

Tarigan, A. K., Nasution, S. D., Suginam, \& Karim, A. 2016. Aplikasi Pembelajaran Citra dengan Menggunakan Metode Computer Assisted Instructiona (CAI). Jurnal Riset Komputer (JURIKOM), 3(4): 1-4.

Tinambunan, A., Ginting, G. L., \& Panjaitan, M. 2018. Perancangan Aplikasi Rambu-Rambu Lalu Lintas untuk Anak Usia Dini Berbasis Android Menggunakan CAI (Computer Assisted Instruction). Jurnal Riset Komputer (JURIKOM), 5(3): 290-295.

Ulfa, K. \& Syahrizal, M. 2016. Perancangan Aplikasi Prediksi Jumlah Siswa Baru pada Yayasan Cerdas Murni Menggunakan Exponential Smoothing. Jurnal Riset Komputer (JURIKOM), 3(6): 59-64.

Wahyudi, T., Mesran, Butarbutar, L. H. O. A. 2015. Perancangan Aplikasi Permohonan Kerja Praktek Prodi Teknik Informatika (Studi Kasus: STMIK Budi Darma). Jurnal Riset Komputer (JURIKOM), 2(6): 73-76.

Wahyuni, S. N. \& Hapsara, M. 2015. Analisis Perancanaan Waktu Proyek Sistem Informasi Menggunakan Critical Path Method dan Metode Kurva Pangkat. Seminar Nasional Aplikasi Teknologi Informasi (SNATI), 2015: C11-C16.

Zukri, Z. \& Winarko, E. 2014. Rancangan Business Intelligence pada Instalasi Farmasi Rumah Sakit. Seminar Nasional Aplikasi Teknologi Informasi (SNATI), 2014: B46-B51. 